\title{
Culture Impact on Consumers Decision: The Fashionable Adoption Influence on Social Stigmatization and Role of Perceived Innovation
}

\author{
Hesham Fazel \\ Business Administration Department, University of Bisha, Bisha, Saudi Arabia
}

Email address:

HFAZEL@UB.EDU.SA

To cite this article:

Hesham Fazel. Culture Impact on Consumers Decision: The Fashionable Adoption Influence on Social Stigmatization and Role of Perceived Innovation. Science Journal of Business and Management. Vol. 5, No. 1, 2017, pp. 17-26. doi: 10.11648/j.sjbm.20170501.13

Received: November 24, 2016; Accepted: December 13, 2016; Published: February 3, 2017

\begin{abstract}
Fashionable product choices can lead to social stigmatization. Embracing a religious ideology may affect the way we evaluate our religious practices (e.g., veil). In this paper, we argue that some of our own religious practices can be stigmatized. The paper examines the psychological keystones of fashionableness adoption and levels of stigmatization. Salafi ideology is presented as a context that may play a role in clarifying the relationship between fashionableness adoption and social stigmatization. The study's findings present main effect of fashionable adoption on social stigmatizing. Moreover, findings show that perceived innovation mediates the relationship between fashionableness adoption and social stigmatization.
\end{abstract}

Keywords: Stigmatization, Fashionable, Product, Innovation

\section{Introduction}

Note this study is done to understand the relationship between apparent growth in cultural ideology; in particular "Islamic movements" a strong sub-cultural ideology, and social stigmatization on a particular consumer behavior. The study context is the Salafi thought. The rise or perceived rise of religious movements is not limited to Islamic ideologies. This research is applicable to any movement based on culture or religious ideology. This is done to investigate relationships through which other religion and culture communities can be compared, linked, and distinguished.

After the event on $11^{\text {th }}$ September, veil appear wearisome to many Muslim women and perhaps even to some men. It is among the most visible markers of the so-called Islamist threat to Western liberal and secular order. Immediately after the event, such stigmatization was based on fear, anger, and a feeling of rejection. There are many stories of how veil or Hijab inspired fear and anger in general population. While veil is perceived as repressive to Westerners, some Turkish women adopted it in a non- traditional and more fashionable style. Looks with a veil on seemed to some a sign of deviance from the Western values of their peers. It was perhaps more tolerable to Westerners [1].
Today, people are more aware of different Islamic sects (e.g., Islamism, Salafism, Sheisim). There is a resurgence of political Islam, and one of the factors causing this renewed activity is Arab spring movement. Each ideology is constructed with a different understanding and interpretation of Islamic values and norms. Such differences are reflected in their evaluations and views on different events and phenomena. For example, people who choose to wear fashionable and stylish veil are stigmatized for not practicing or following values based on authentic and reliable, sources. The stigma herein is based on a perception of transgressing group values, immorality, disgracefulness and immodesty.

[1] advanced the work on stigma by shifting focus from coping strategies [2] [3] to the processes through which a stigmatized practice becomes an attractive choice changing its status. The Authors demonstrate how religious beliefs intertwine with political tensions and historical structures to transform wearing a veil from a stigmatized practice to a fashionable clothing choice. [4] examined how Islamism informs consumption discourses and practices. By tracing the socio-historical construction of infidel brands, she explicates how consumers draw from religious myths, local ideological 
tensions, global events, and historical conflicts, to construe global brands as ideological threats to Islam. These findings suggest that characterizing particular brands as a threat to the virtues of an ideal Islamic society (e.g. Modesty), as inscribed in the Islamic myth of the Golden Age, drives informants to forge a "consumer jihad" against these antagonist brands.

From these two remarkable studies, this study discusses another aspect that departs mainly from the basic understandings of both researches' outcomes. Specifically, chosen fashionable veil may lead to an escalation in stigmatization. Muslims are admittedly divided into a variety of denominations and sects that construct different understandings and interpretations of some Islamic teachings. These differences lead to divergence in observing and evaluating every single event and activity related to Islamic life [5].

The revolutionary wave of demonstration and protests occurred in the Arab world and began on December 2010. Rulers were forced out of power in Tunisia, Egypt, Libya and Yemen; civil uprising have erupted in Bahrain and Syria, and major protests have broken out in Algeria, Iraq, Jordan, and Sudan. There were reports of many other demonstrations and protests in the region [5]. As a consequences many religious (e.g., Salafism), liberalists, and extreme culturists emerged. Salafism became more popular in Arab countries where dictators ruled with iron fist were removed by these unprecedented uprisings. As an example, Al-Nour Party in Egypt was founded in 2011 and the Egyptian Homeland Party (Alwatan) was founded in 2012, It also included the Ennahda Movement (known as Renaissance Party) in Tunisia, Ansar al-Sharia in Libya that was formed during the 2011 Libyan revolution and many others [6].

Salafism as an ideology stands for the school of thought that takes al-salaf al-salih, the (pious ancestors), as its only point of reference. It does not attempt to provide new interpretations or views other than those already exist. Its main preoccupation is with the fundamentals of the faith and doctrinal purity [7]. For example, in general, Islam gives guidance about all aspects of life, including matters of public decency. Islam specifies that overall appearance of a person should be dignified and modest. It has no fixed standard as to the style of dress or type of clothing that Muslims must wear. However, some minimum requirements must be met [8] [9].

According to salafism dresses and clothes should be worn in the same, as did al-salaf al-salih. Dress must be modest and loose enough to not outline or distinguish the shape of the body. Women clothing should not attract men's attention. It should not be shiny or flashy. Accordingly, shiny and fashionable clothing that attract attention may not meet the requirements of al-salaf al-salih's way of clothing and thus challenge Islamic authentic teachings [6]. Salafism creeds consider the dress code of believing women in the time of Prophet-hood as a source of guidance for Muslim women in modern times. Islamic teachings are not confined to a particular era or location, rather the beauty of Islam is there for all times to come, to all places, and invite all people to it
[10]. However, the meanings and forms of veiling have changed tremendously in recent Islamic history which may not be acceptable by the salafies and may be perceived as a form of reprehensible innovation that lead people to go astray from the right path of Islam.

The paper explores several key questions: how people who embrace salafi thoughts evaluates fashionable consumption and practices. The argument is that salafies perceive the adoption of fashionable, careful and stylish veil as a deviation from the authentic teachings of Islam. Therefore the question is, do salafies stigmatize adopters of fashionable veils and if so why? When [1] discussed how people might use stigmatized consumption for their benefit. They may transform it into a powerful tool changing the status of being stigmatized to being fashionable and stylish. I must look at the ramifications of such processes and transformations to ingroup members' perception and evaluation of such action. This paper explores how such consumption and transformation of Islamic value are perceived in different groups or sects and the general question is; can such consumption affect the way people evaluate or interact with each other?

\section{Literature Background}

\subsection{Veil in Style and Stigmatization}

One implication that arises from society's following values and norms of groups is that, when people engage in behaviors that deviate from the group's view, they risk being sanctioned [2]. One form of social sanction is stigmatization of the deviating behavior. Stigmatization occurs when an individual possesses an actual or believed trait, characteristic, or behavior that is undervalued or perceived negatively in a given social context [11] [10]. Research has demonstrated that being stigmatized has significant negative consequences for a person [11] [12] [10]. This can be seen in a variety of consumer settings, such as the treatment of smokers by nonsmokers [13] or veiling, a practice laden with stigmatization in the Western mind-set [14].

According to [15] stigma is an attribute that dishonors an individual, reducing him or her "from a whole and usual person to a discounted one. [12] Proposed that stigmatization occurs when a person possesses (or is believed to possess) "some attribute or characteristic that conveys a social identity that is devalued in a particular social context" (p. 505). According to these definitions, people who are stigmatized have (or are believed to have) some attributes that mark them as different and lead them to be devalued in the eyes of others. Stigmatizing may be linked to appearance (e.g., a physical deformity), behavior (e.g., stingy, sinners), or group membership (e.g., American-Muslim, African-America). Importantly, stigma is relationship and is context specific; it does not reside in a person but in a social context. Most scholars regard stigma as a social construction a label attached by society and point to variability across time and cultures in what attributes, behaviors, or groups are 
stigmatized [12].

Contemporary perspectives on stigma emphasize the extent to which stigma effects are mediated through targets' understanding of how others view them, their interpretations of social contexts, and their motives and goals. These theories are "top-down" in their emphasis on how people's construal of their environment and self-relevant motives (e.g., self-esteem protection) shape their emotions, beliefs, and behavior. They are also "bottom-up" in their assumption that construal emerge from experiences with being a target of negative stereotypes and discrimination [10]. These perspectives assume that stigma puts a person at risk of experiencing threats to his or her social identity. [12] for example, stated that " stigmatization threatens self-esteem (personal and collective), and can lead to attributional ambiguity, i.e., uncertainty as to whether outcomes are due to one's personal identity or social identity". [11] on the other hand, hypothesized that negative self-relevant group stereotypes could lead to stereotype threat. He mentioned that cultural knowledge or situational cues that indicate one's group is devalued, marginalized, and low status lead to social identity threat, i.e., a threat to the aspect of self that is derived from membership in a devalued social group or category [22].

Accordingly, a fashionable practice might become a threatening choice to a certain group's identity (e.g., salafism), and may develop stigmatize perception against those who invented a consumption that contradicts the core values of the group. When particular practices such as wearing fashionable and stylish veils are thought to be a salvation from an out-group negative evaluation, it may from another end- develop the same negative evaluation and stigmatization from in-group members by evaluating fashionable and veils as a wrong innovation and view innovation adopters as sinners.

One of the ways that stigma impacts social interaction is evaluation cues, which is information derived from a situation that may trigger cognitive or affective responses to the stigmatized target [17]. Evaluation cues can take the form of sensory cues (e.g. visual cues such as skin color) or auditory cues (e.g., foreign accent) or more explicit information tied to symbolic meaning that is associated with stigmatized individuals. The process of stigma with regards to racial, ethnic, or religion involves cueing of certain evaluation associated with that particular known stigma and the associated expectations of such that serve to elicit responses based upon those expectations [18].

The important consequences of stigma are not only relevant to social interactions that are on an individual level but also for the broader social implications tied to institutional discrimination and social ideologies that support such beliefs [19]. The keyword here is power. The meaning of stigma with respect to social relations between those who are stigmatized and those who are not is that of power relationship (e.g. the belief that one social group is as inferior as to be dismissed and that the other group is superior [18].

Although research suggests that stigma is process linked to social status in that there is status loss. Researchers simultaneously argue that stigma places individuals as outsiders. This particular process of isolation and social distance related to stigma is contradictory to the notion of stigma as part of the status process itself, according to status characteristics theory. Stigma prevents the individual from having typical social interactions and their involvement is seen as awkward in social relations [20]. Stigmatized people are often avoided during social interactions and they experience greater social distance from others, resulting in feelings of isolation. Therefore, the purpose of this study is to determine a better understanding of the social psychological processes involving stigma in relation to salafi ideology [21].

\section{Salafism Ideology}

In general ideology is a "motivated thought" which aims to totalize the information received by an individual concerning his/her natural and social environment. The process includes additional levels of reality accessible through "common sense thought" [22]. As Tanner notes, this kind of thinking is " not unrelated to the practical goals of everyday life, but it stands apart from common sense thought", in that it offers quite separate techniques to produce these goals [23].

A religious commitment is often at the core of an individual's sense of identity. Social scientific studies of religion have shown variety of ways in which religions robustly serve as the identity instinct. As [24] states, "Religions often serve numerous psychological needs more comprehensively and potently than other repositories of cultural meaning that contribute to the construction and maintenance of individual and group identities." Religion generally provides its groups with a discrete theology and a coherent and constant set of norms, institutions, traditions, and moral values that serve as a basis for a group or an individual to establish and maintain firm identity. When an individual has decided upon a religious identity, that person often feels a need to translate and explicitly express this chosen identity through interactions with others [25].

There are numerous instances in which religion -as an ideological force- shows the significance role that can play in people's lives. For instance, consumption norms may facilitate the communication of religious ideological belief. Whenever an individual violates the meaning of these norms it presents a wrong image to the entire group. Once others know of an individual's offense concerning his/her own religious or cultural values, they may view the violation as something that derogates that group's values [26]. Religion normally provides a distinctive set of consumption norms that become an outline for its followers [27]. For example, Muslims express their consumption guidelines by obtaining halal products. Muslim women express their religious commitments by wearing a veil or headscarf, and people are prone to interpret veil as a sign of her identity [28] [29].

Salafism ideology stands for the school of thought that takes al-salaf al-salih, (pious ancestors). The concept is used to 'purify' Muslims from their present realities, histories, theologies, jurisprudence, and contexts in order to move them ironically into either a backward and regressive religious, 
moral, social, and political trajectory, or into a forward and progressive religious, moral, social, and political forward trajectory [6]. Consequently, the concept of salaf could lead an individual, a group or community forward or backward. Many Muslim reformers or modernists employ the concept of salaf, it does not make them salafists, a fact that remains unrecognized by the vast majority of experts on Islam [30].

Salafism is dedicated on reforming individuals and communities on the basis of true teachings of Islam according to Qur'an and Sunna (prophetic traditions) as understood and practiced by al-salaf al-salih. Salafists believe that some communities moved in the direction of diverse forms of polytheism, reprehensible innovation, and superstition. Thus, neglecting 'the purist' interpretation of Islam that of al-salaf al-salih is equivalent to neglecting Islam itself. Consequently, all religious, intellectual, social, doctrinal, political conflicts have resulted from the failure to follow the method of al-salaf al-salih [31].

Salafies are united by a common religious faith, which provides principles for applying religious beliefs to contemporary issues and problems. This faith revolves around firm devotion to the concept of tawhid (the oneness of God) and rejection of a role for human reason, logic, and desire [32]. By strictly following the rules and guidance in the Qur'an and Sunna (Prophetic traditions) salafies believe that they are able to eliminate the biases of human subjectivity and selfishness. This allows identification of singular truth about God's commands. From this perspective, there is only one legitimate religious interpretation; Islamic diversity does not exist [33].

Salafism is not Islamism in the classical or hierarchical sense. It is rather closer to a socio-religious current that is loosely structured around the relationships built between sheikhs (religious scholar) and their students (disciples or followers) [30]. Salafies organize and commit by way of religious instruction, classes, seminars, discussions, joint activities and their own particular scholarly approach or intellectual paradigm. They are further distinguished by a publicly declared refusal to engage or participate in political parties, partisan activities or any other institutionalized political, social framework. Such participation is considered contrary to their scholarly approach, intellectual paradigm and school of thought [30].

Salafism focuses on teaching "true" Islam, by referring to the comprehensive principles of creed in order to answer all problems facing the community; to purify Muslim beliefs and practices from the infiltration of elements of reprehensible innovations and unbelief, and consider debating such beliefs and practices as erroneous; to revive the practices of the Prophet Muhammad (pbup) and disseminate the message of solidarity and unity of the community [6]. Salafists believe that this is the effective way to avoid any resemblance to infidels. For the same reason, they also reject all entertaining distractions: music, theatre and places of pleasure and entertainment such as cafés, discotheques, and dance-clubs. Cinema, television and photographs are considered evil innovations and part of infidel cultures. Salafists emphasize that the roots of their concern with the community system lies more in a willingness to withdraw from corrupting innovations and to live in accordance with the examples of al-salaf al-salih, rather than in a revolutionary activism to create a totally Islamic society [31].

Researcher argues that adopters of fashionableness that may bring attention to one's attractiveness in particular when women adopt fashionable veils are more likely to of be stigmatized. Fashionable practices is seen as a threat and contrary to the pure Islamic teachings and may, deviate Muslims from understanding of Qur'an and Sunna (prophetic traditions) as understood and practiced by al-salaf al-salih.

\subsection{The Perception of Innovation}

The original meaning of innovation is (bid ' $a$ in Arabic language) "to start or begin something novel" [34]. Among the many words directly resultant from the root of

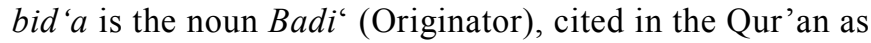
an attribution of God: "Originator (badi') of the heavens and the earth" (Quran 2:117; 6:101). Use of Badi' with reference to God signifies the uniqueness of God's creative act and infers that the universe came into existence without a previously existing prototype [35]. As an adjective, badi ${ }^{6}$ was applied to outstanding works of human intellect, especially those masters of the spoken and written word [36].

Culturally, innovation (bid'a) refers to that part of cultural value system that has no originality or basis what so ever in Islamic or tribal cultures [37]. The pre-Islamic

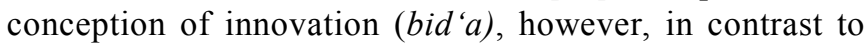
later Islamic usage, tended always to be negative and served as a critique of the social implications of noncustomary practices [38]. When something was categorized as an innovation (bid 'a), meant that it violated the tribal codes and norms. An innovation was an action or an idea that lacked standard in recognized custom. It instituted a sort of tribal heresy, a hateful innovation caused by deviating from the ways of patriarchs of the past [38].

In traditional Islamic thought, the concept of innovation (bid'a) is not always well understood. The allegation that something is an innovation (bid ' $a$ ) is often made thoughtlessly to disregard new ideas [35]. Islam is a complete religion and new ideas are unaccepted because of the implication that Islam is incomplete or defective needing innovations. As for the words "that does not belong to it," they indicate that innovating something that is in accordance with the Qur'an and Sunna (i.e. "which belongs to it") cannot be considered reprehensible. Imam Shafi'i said, "Any innovation that violates the Qur'an or Sunna is a deviance. Anything good that has been innovated which does not contravene any of the above is not reprehensible" [39]. Therefore, reprehensible innovation (bid'a) is any new way in worship that is done with the intention of attaining more reward from the Almighty, but is not proven by the words or the actions of the prophet (pbuh), prophet companion, or al- 
salaf al-salih. When there is doubt about whether or not something is a reprehensible innovation, a better way is to leave the action.

According to [39] (a member of the Permanent Committee for Islamic Research and Fatawa in Saudi Arabia), the innovators who bring something that is not based on Qur'an or Sunna should not be praised because praising and commending innovators will spread and promote his/her innovation. Al-salaf al-salih used to warn against trusting the innovators, praising them, or even accompanying them. [39] stated that al-salaf al-salih used to say, "Whoever sits with an innovator has assisted in the destruction of the Sunna," With this practice (praising the innovator), the innovators will get the upper hand and they will become the leaders of Islamic nation. Therefore it is obligatory to warn people about them.

However, in classical Islamic theology, innovation could take on various meanings. When used without qualifying adjectives, it tends to be condemnatory, for example, in the statement, innovation must be avoided." Nevertheless, innovation is not always bad. In certain contexts, especially when qualified by adjectives, innovation could cover a wide range of meanings from what was admirable to what is completely wrong. For many Muslims, the word innovation (bid'a) invariably designates extreme religious error and evokes negative emotions that are so passionate that the matter is put beyond any possibility of reasonable discussion [35].

Salafies believe that human desires continue to hold and may corrupt Muslims and corrupting the message of Islam. In this view, there is an endless temptation to manipulate and change the religion through innovations (bid'a). Although reprehensible interests often drive deviancy, it can also result from good intentions [32]. As an example, Muslims who pray more than the explicitly proscribed five times a day as an obligatory duty are likely motivated by love for God. They are, however, still engaged in innovation because they are inventing new practices to fulfill human desire [37].

Many innovations, according to salafies, resulted from the expansion of Islam to new locales, where practitioners blended local culture with Islamic traditions. This helped conversion by rendering Islam accessible through local dialect and customs, but salafies cite this syncretism as a major source of innovation. Cultures are thus seen as the enemies of pure Islam [35]. As [40] argues, one of the primary objectives of fundamentalist groups like salafism is "de-culturation". They seek to practice Islam, which is untouched by any foreign elements. They do this by abandoning folk customs and disassociate Islam from any cultural contexts. This makes salafism agents of a new globalized Islam. Their faith is explicitly intended to go beyond local space, traditions, and religious authority by connecting Muslims to an imagined community of true believers.

Generally, designing fashionable veils is like inventing and introducing a modernized perception to the overall understanding of Islamic veil [37]. Salafies emphasize more on following "al-salaf al-salih" and strive to reflect salafism ideology on defining features in ascertaining their category memberships. Salafies are more prone to evaluate products (e.g., veil) based on the understanding and interpretations of al-salaf al-salih, with no inventions or additions to the definitions and original features. Therefore, they are more stringent against products containing features that may deviate from this ideological view. Transforming products original features by adding or developing new "fashionable" and "stylish", "flashy" and "attractive" features that might be attractive to some women but is fundamentally forbidden according to salafism.

Figure 1 illustrates the theoretical framework of this research. It shows adoption of fashionableness as an influential factor that may induce social stigmatizing. Also fig. 1 shows the mediation role of perceived innovation.

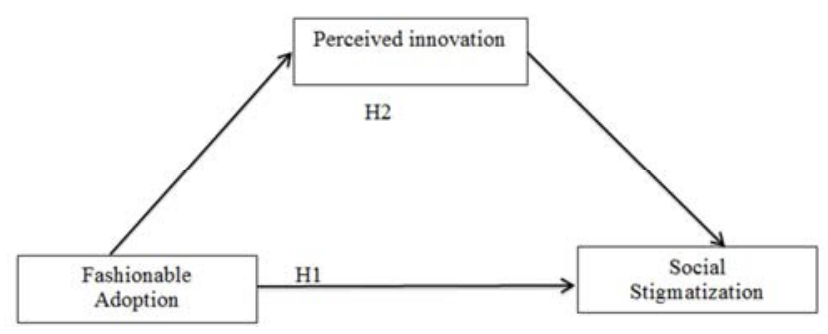

Figure 1. Theoretical framework.

\section{Methodology}

The first objective of conducting this study is to test the effect of adopting fashionableness on social stigmatization within a religious framework (herein, salafism ideology). The second objective is to discover the mediation role of perceived innovation. Experimental study design is applied to test the proposed relationship. The experimental design seeks to isolate causal relationships by manipulating the proposed causal variable [41] [42]. For the purposes of this study, the experimental design has important advantages. First, it allows the researcher to examine the influence of adopting fashionableness in the sensitive framework of religious group (sect) on stigmatization. Because the subjects are randomly assigned to conditions, the differences in responses to the two experimental conditions should be attributed to variations in the stimulus rather than to variations in respondents' characteristics [42].

Pretest. The objective of the pretest is to determine the perception of the differences of perceiving fashionableness veils for Muslim women within a salafi majority community that should help us understand the differences in viewing and perceiving veils based on diverse understanding and interpretation of Islamic teachings. 28 Muslim women participants were exposed to four different veils' pictures. These four pictures were with veils on the same model's face and veils were extended from standard and traditional black veil to being colorful and embroidered. Participants were asked on a seven point scale; $1=$ not at all and $7=$ very much, of the veil fashionableness and stylishness. 


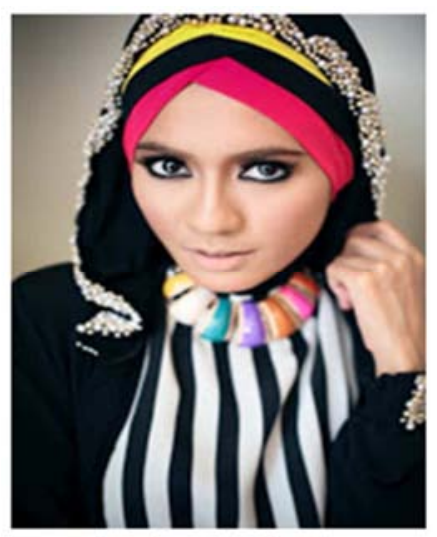

Figure 2. (Hijab Fashion 1).

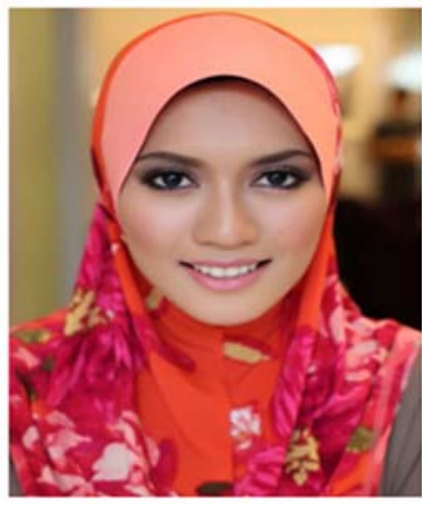

Figure 3. (Hijab Fashion 2).

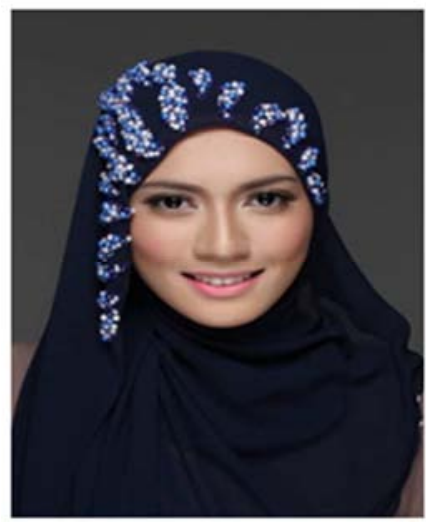

Figure 4. (Hijab Fashion 3).

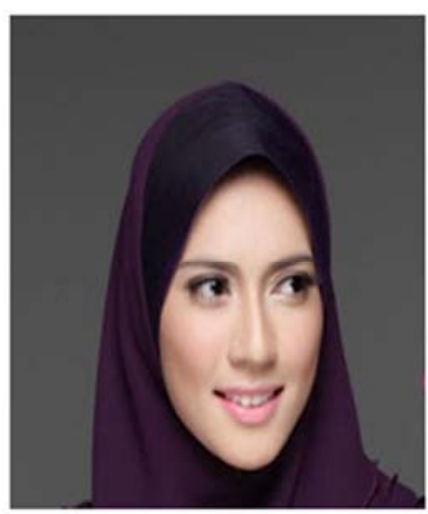

Figure 5. (Hijab Fashion 4).
A repeated measures ANOVA with a Sphericity assumed correction determined that mean of veil fashionableness (stylish) perception statistically differed significantly among veils $F(33,66)=3.708, p<0.05)$. Post hoc tests using the Bonferroni correction revealed that veil 4 was perceived as the most fashionable veil. It differed significantly from veil3, $(M v e i 14=3.59$ vs. $M$ veil3 = 2.46). Post hoc tests showed no other significant differences between the veils. We can, therefore, conclude that among the four veils, veil4 and veil3 are the only veils that were significantly different in fashionableness perception.

\subsection{Main Study}

Stage 1: Exploring Research Framework.

The objective of stage. 1 was to examine research framework through finding out the level of embracing and accepting salafism ideology among the prospective population of the study sample. This was done to determine its suitability for conducting this study. To measure salafism ideology among the study's population sample, format applied by [43] was adopted. Samples of conservative Arab salafi clerics writing statements were selected. The degree of agreement or disagreement with each statement among participants was measured. Through using percentage measurement participants' level of acceptance salafism ideology was defined. Clerics were randomly sampled for analysis based on two conditions. Analysis was limited to conservative Arab salafi clerics and also included clerics based on perception of their importance and influence. Participants were confronted with five statements and were asked to rate their agreement or disagreement with each statement. Table 1 gives an overall descriptive statistics of the sample population for this research. Figure 6 illustrates the religious ideological belief of salafism among the study population.

Table 1. Study Descriptive Analysis.

\begin{tabular}{|c|c|c|c|c|c|}
\hline \multicolumn{6}{|c|}{ Descriptive Statistics } \\
\hline & $\mathbf{N}$ & Minimm & Maximum & Mean & $\begin{array}{l}\text { Std. } \\
\text { Deviation }\end{array}$ \\
\hline Salafism Ideology & 55 & 2.20 & 6.20 & 4.509 & .91313 \\
\hline
\end{tabular}

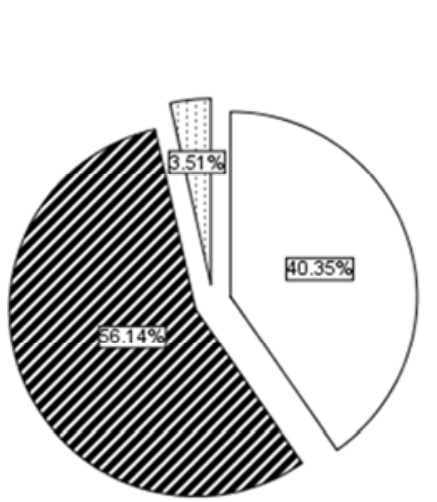

Salafism-Level

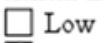

V. High

Missing

Figure 6. Level of embracing Salafism ideology among the population of the study sample. 
From the above given statistical information the majority of population were highly embracing salafism ideology with a sample mean of 4.50 . Therefore, it may be concluded that the framework of this study is fairly suitable to test the proposed relationship between fashionableness adoption and social stigmatization, controlling for salafism ideology as a critical contextual factor.

Stage 2: Main effect \& Mediation effect.

The objective of this study was first to test the main causation effect of the independent variable "fashionableness adoption" on the dependent variable" social stigmatization". Second was to examine the psychological underpinnings of "perceived innovation" differences as a mediation factor on fashionableness adoption and social stigmatization relationship. To measure the dependent social stigmatization variable, social distance was measured, which is the operationalization of stigma in this study. This was done by examining how willing the participant would be to make friends with the target applicant, how willing the applicant would be to start working closely with the participant on the job, and how willing the participate would be to accept having the target applicant move into a house on his/her block or neighborhood $(\alpha=72)$. To measure perceived innovation I partially adopted the work of [44] [45]. I utilized the relevance -7 - items $(\alpha=94)$ that represented two attributes; compatibility and image.

The experiment has two conditions, condition 1(fashionable adoption,) condition 2 (No-fashionable adoption). An open invitation to participate in an online survey was sent to 150 individuals. Fifty-five individuals completed the survey, for a final response rate of $37 \%$. The average age of the sample was 30 , and $48 \%$ of participants were male.

\subsection{Procedure}

The participants were assigned randomly to one of the two conditions. Participants were asked to read a hypothetical scenario where they were advised that he or she is an owner of newly opened clothing store and he/she is looking for new employee to work in the store. Participants were given a brief description of the requirements for the position and were asked to make a decision on hiring the target (applicant). In addition to the scenario, a small photograph was attached with application information of the target (applicant). The applications were identical in all conditions except the target picture. In one picture the target was wearing more fashionable veil based on general understanding of fashionableness (embroidery, stylish, shiny ...etc.) that represented one end of the conditions, whereas, the other picture the target was wearing a traditional black veil that represented the other end of conditions (see appendix A). Both pictures were identified to be different from each other based on pretes. 1 (see pretest.1).

Since all measurement scales used in this study [43] [44] [45] were originally developed in English, the questionnaire was also first constructed in English. Afterwards, two bilingual professional translators who were blind to the conditions and predictions of the research were recruited to translate the questionnaire into Arabic language and retranslate it back to English. One of the translators translated the questionnaire into Arabic language. Then, the Arabic translated questionnaire was given to the other translator who translated it back to English language. The translations were verified through discussions with them. The questionnaire was designed for respondents to complete in 15 to 20 minutes. At the end of the study, participants were asked about some demographic information and thanked for their participation in the study. They were thoroughly debriefed on the purpose of the study.

\subsection{Main Effect}

One-way ANOVA was conducted to test the main relationship between the independent variable of adopting fashionableness and the dependent variable social stigmatization. The results show a significant main effect of adopting fashionableness on social stigmatization toward those who adopted fashionable and stylish veil $(M$ fashionable $=2.85$, Mno-fashionable $=2.30 ; \mathrm{F}(1,54)=$ 4.43, $\mathrm{p}<.05)$.

\subsection{Mediation Effect}

To test whether the perception of adopting or utilizing innovation mediate this relationship, path analysis was conducted with stigmatization as a dependent variable, fashionableness as an independent variable, and perceived innovation (innovation reflects on the stylish and fashionableness of veils) as a mediator (see Figure 7). According to Baron and Kenny (1986), to prove mediation, $\beta$ coefficients of three regression equations must be estimated and compared with one another: (a) first, the presumed mediator should be predicted by the independent variable; (b) second, the dependent variable should be predicted by the mediator and by the independent variable; and (c) last, controlling for the mediator the independent variable should no longer predict the dependent variable.

The appropriate regression equations were estimated according to this procedure. In the first equation, fashionableness was found to be significantly related to the dependent variable stigmatization $(\beta=-.549, \mathrm{p}<.05)$. In the second equation, fashionableness was found to be significantly related to the mediator of perceived innovation $(\beta=-1.10, p<.05)$. In the third equation, controlling for the mediator, the effect of dispositional need for fashionableness on stigmatization dropped to nonsignificance $(\beta=-.35)$ whereas the effect of the mediator remained significant $(\beta=-.332, p<.05$. Indirect effect Sobel test shows a significant value $(p=.056)$ that indicates that "perceived innovation" is a significant mediator between the IV and DV; figure 7 illustrates this relationship. 


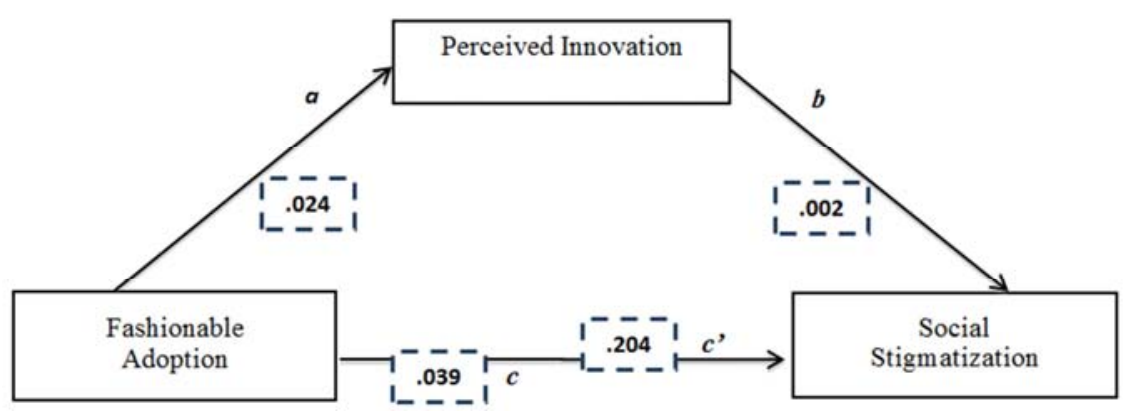

Figure 7. Perceived Innovation as a Mediator.

This finding further supports the notion that fashionableness, reflected in the way of adopting and practicing innovated veil that is not historically rooted in the cultural teachings or the veiling style in this research, defines the social stigmatization that fashionable adopters may face. Table 2 illustrates the three steps for path analysis that tested the mediator effect of perceived innovation on the relationship of the independent variable of fashionableness adoption and the dependent variable of social stigmatization.

Table 2. The Steps of Indirect Effect and Values.

\begin{tabular}{lllll}
\hline Step & Path & $\boldsymbol{b}$ & $\boldsymbol{t}$ & $\boldsymbol{p}$ \\
\hline 1 & $\mathrm{c}$ & -.543 & -2.10 & $.039^{* *}$ \\
2 & $\mathrm{a}$ & -1.10 & -2.33 & $.024^{* *}$ \\
& $\mathrm{~b}$ & .244 & 3.28 & $.002^{* * *}$ \\
3 & $\mathrm{c}$ & -.332 & -1.12 & .204 \\
$\mathrm{Z}$ & & $\mathrm{Sig}(p)$ & & \\
Sobel Test. & & 2.0 & $0.056^{* *}$ & \\
\hline
\end{tabular}

$* * *<.01$

$* *<.05$

$*<.10$

\section{General Discussion}

The findings indicate that the perception fashionableness differ between Muslim women. Differences from previous research may arise due to different populations' ideological systems. The context of this study where the majority accepts and embrace salafism helped us understand the differences in viewing and perceiving veils based on diverse understanding and interpretation of Islamic teachings.

In addition, the results of the study provide substantial support for the hypotheses derived from the main effect. The study argues that when consumers adopt fashionable products (e.g., veils), such behaviors are perceived by certain religious ideology (e.g., salafism) as transgressions to the religion's authentic and accepted teachings. Thus they are more likely to be socially stigmatized. In other words, the social distance that measures the level of social stigmatization indicates that fashionable veil increases the likelihood of stigmatization compared to traditional veil.

Also perceived innovation was tested as a mediator factor that may further explains why fashionable adopters are in the zone of being socially stigmatized. As stated before, salafism's understanding and interpretation of Islam see that any innovations in religion are reprehensible and whoever adopts innovation is a sinner. However, the results show that innovation is indeed perceived as reprehensible act and it is significantly mediating the main relationship of fashionableness adoption and social stigmatization.

Theoretically, the study has provided some new information that adds to our current limited stock of knowledge concerning the influence of fashionableness adoption on consumers' social stigmatization and the role perceived innovation might play in this relationship. The study provides support for the position that the perceived innovation serves as a threat to pure and authentic teachings of Islam in the eyes of salafies. Choice of veils and styles might increase social stigmatization for the fashionableness adopters. The main effect of fashionableness adoption on consumers' social stigmatization and the mediation role of perceived innovation stands as the major contribution of this research since, until now, the existing literature on the subject have not covered the relationship in these dimensions.

Previous research by [1] has suggested that stigmatized practice becomes an attractive choice and its stigma status changes. The present research, however, suggested that attractive choice could develop stigmatization when it is perceived as a threat or transgression of the in-group valuable teachings. The finding contributes to the existing literature on social stigmatization in several important ways. First, the findings indicate that individual differences in experiencing social stigmatization are based on a certain ideological system. Different understanding and interpretation of culture values and religious teachings impose different set of evaluation criteria. Second, the research findings provide a novel demonstration that in some cases, salafies perceive innovation as an erroneous way to practice Islam and perhaps may stigmatize innovation adopters (e.g., fashionable veil).

Managerially, this study should serve to broaden the vision of marketing managers by helping them to understand the relationship between fashionableness, innovation and stigma. More specifically, managers should consider reactions of groups that base their values on religious systems as it relates to consumer emotions that exist within different religious backgrounds. The research's findings suggest that marketers need to know how their customers feel about their consumption experiences, and the environmental factors that may affect their customers' consumption experiences and emotional reactions. 


\section{Conclusion}

In this study, the researcher executed an attempt to understand the relationship between the rapid growth in cultural ideology and overall practices with social stigmatization. The researcher have done the study on one sect of all Islamic sects. Therefore, surely this research can be replicated on any movement that are centered on culture or religious philosophy.

Research undertakes a theoretical and an empirical exploration into this problem and come up with some investigative hypotheses. Based on the the results show above, Researcher has a high confident to articulate that adopters of fashionableness that may bring attention to one's attractiveness are more likely to of be stigmatized by the adopters' own community. Fashionable practices is seen as a threat and contrary to the pure Islamic teachings and can be seen as an absolute deviation from the understanding of Qur'an and Sunna (prophetic traditions) by al-salaf al-salih.

As of most research papers the findings of this paper is limited to only one type of product (veil) and to only one aspect of group consumers and as well as one sect of Islamic understanding. Investigating the potential differences among other groups and in other consumption contexts represents a suitable path for future research. Also, other coping strategies that follow social stigmatization in this particular context, which are a promising prospect for future research.

\section{References}

[1] Sandikci, Ö., \& Ger, G. (2010). Veiling in style: How does a stigmatized practice become fashionable?. Journal of Consumer Research, 37 (1), 15-36.

[2] Argo, J. J., \& Main, K. J. (2008). Stigma by association in coupon redemption: Looking cheap because of others. Journal of Consumer Research, 35 (4), 559-572.

[3] Conrad Henry, P., \& Caldwell, M. (2006). Self-empowerment and consumption: Consumer remedies for prolonged stigmatization. European Journal of Marketing, 40 (9/10), 1031-1048.

[4] Izberk-Bilgin, E. (2012). Infidel brands: unveiling alternative meanings of global brands at the nexus of globalization, consumer culture, and Islamism. Journal of Consumer Research, 39 (4), 663-687.

[5] Abulof, U. (2011). What is the Arab third estate?. The Huffington Post, 10.

[6] M. Almossawi, M. (2014). Impact of religion on the effectiveness of the promotional aspect of product packages in Muslim countries. Asia Pacific Journal of Marketing and Logistics, 26 (5), 687-706.

[7] Shimek, E. D. (2012). The Abaya: Fashion, Religion, and Identity in a Globalized World.

[8] Syed, J. (2008). From transgression to suppression: implications of moral values and societal norms on emotional labour. Gender, Work \& Organization, 15 (2), 182-201.
[9] Syed, J., Ali, F., \& Winstanley, D. (2005). In pursuit of modesty: contextual emotional labour and the dilemma for working women in Islamic societies. International Journal of Work Organisation and Emotion, 1 (2), 150-167.

[10] Steele, C. M. (1997). A threat in the air: How stereotypes shape intellectual identity and performance. American psychologist, 52 (6), 613.

[11] Crocker, J. (1999). Social stigma and self-esteem: Situational construction of self-worth. Journal of Experimental Social Psychology, 35 (1), 89-107.

[12] Crocker, J., \& Quinn, D. M. (2000). Social stigma and the self: Meanings, situations, and self-esteem. The social psychology of stigma, 153-183.

[13] Gibson, B. (1998). Nonsmokers' Attributions for the Outcomes of Smokers: Some Potential Consequences of the Stigmatization of Smokers. Journal of Applied Social Psychology, vol. 28,no. 7), pp. 581-94.

[14] Göle, N. (2003). The voluntary adoption of Islamic stigma symbols. Social Research, 809-828.

[15] Goffman, E. (1963). Stigma: Notes on the management of spoiled identity.

[16] Goffman, E. (2009). Stigma: Notes on the management of spoiled identity. Simon and Schuster.

[17] Blascovich, J., Spencer, S. J., Quinn, D. M., \& Steele, C. M. (2001). Stereotype threat and the cardiovascular reactivity of African-Americans. Psychological Science, 12, 225-229.

[18] Al-Mutawa, F. S., Elliott, R., \& Nuttall, P. (2015). Foreign brands in local cultures: A socio-cultural perspective of postmodern brandscapes. Journal of Consumer Behaviour, 14 (2), 137-144.

[19] Dolbec, P. Y., \& Fischer, E. (2015). Refashioning a field? Connected consumers and institutional dynamics in markets. Journal of Consumer Research, 41 (6), 1447-1468.

[20] Belk, R. (2014). Digital consumption and the extended self. Journal of Marketing Management, 30 (11-12), 1101-1118.

[21] Stangor, C., Swim, J. K., Van Allen, K. L., \& Sechrist, G. B. (2002). Reporting discrimination in public and private contexts. Journal of personality and social psychology, 82 (1), 69.

[22] Tanner, Adrian. (1979), Bringing Home Animals: Religious Ideology and Mode of Production of the Mistassini Cree Hunters, ISER, and St. John 's.

[23] Abrahamov, B. (1998). Islamic theology: Traditionalism and rationalism, Edinburgh University Press, Edinburgh.

[24] Seul, J. R. (1999). Ours is the way of god': Religion, identity, and intergroup conflict. Journal of Peace Research, 36 (5), 553-569.

[25] Martinovic, B., \& Verkuyten, M. (2016). Inter-religious feelings of Sunni and Alevi Muslim minorities: The role of religious commitment and host national identification. International Journal of Intercultural Relations, 52, 1-12.

[26] Shahin, E. E. D. (Ed.). (2016). The Oxford Handbook of Islam and Politics. Oxford University Press.

[27] Koch, A. (2016). Economics of Religion. 
[28] Metin, C \& Lanse M, (2004), "Religious Identity and Consumption, "Review of Social Economy, Taylor and Francis Journals, vol. 62, no. 3, pp. 339-350.

[29] Kumar, V. (2008). A critical review of economic analyses of religion. Available at SSRN 1193862.

[30] Abu Rumman, Mohammad. Abu Hanieh, Hassan. (2010). Jordanian Salafism: A Strategy for the "Islamization of Society" and an Ambiguous Relationship with the State" Economic Printing Press, Amman, Jordan, Published in 2010 by Friedrich-Ebert-Stiftung.

[31] Khan, A. K. (2013). Global Salafism: Islam's New Religious Movement. Nova Religion: 17 (2), 106-108.

[32] Shultz Jr, R. H. (2008). Global Insurgency Strategy and the Salafi Jihad Movement (No. INSS-OP-66). Inst for national security studies us air force academy co.

[33] Wiktorowicz, Q. (2006). Anatomy of the Salafi movement. Studies in Conflict \& Terrorism, 29 (3), 207-239.

[34] Ahmad ibn Faris, Mu 'jam Maqayis al-Lugha, 6 vols. (n. p.: Dar al-Fikr, 1979), 1:209; al-Raghib al-Isfahani, ed. Safwan 'Adnan Dawudi, Mufradat Alfaz al-Qur'an (Damascus: Dar al-Qalam, 1992), 111; Abu Ishaq al- Shatabi, Al-I'tisam, 2 vols. (al-Khubar, KSA: Dar Ibn 'Affan, 1997), 1:49.

[35] Abd-Allah, U. F. (2006). Innovation and creativity in Islam. Artikkel, Nawawi Foundation.

[36] Ismail, S., \& Shaari, M. S. (2015). Fostering creativity in the Islamic world: towards an effective islamic creative industry. History, 5 (16), 111-119.
[37] Wiktorowicz, Q. (2006). Anatomy of the Salafi movement. Studies in Conflict \& Terrorism, 29 (3), 207-239.

[38] Juynboll, A. (1984). Muslims' Introduction to His Sahih: Translated and annotated with an excursus on the chronology of fitna and bid 'a. in Jerusalem Studies in Arabic and Islam, no. 5. 308; Mohammad Kamali, Principles of Islamic Jurisprudence (Cambridge: Islamic Texts Society, 1997), 44.

[39] Fawzan,S. (2012). The call of the salaf is true Islam. Published on 30 Aug 2012, by ahlul sunnah waljammah.

[40] Munson, H. (2005). Globalized Islam: The Search for a New Ummah. The Middle East Journal, 59 (1), 161Adkins, N. R., \& Ozanne, J. L. (2005). The low literate consumer. Journal of Consumer Research, 32 (1), 93-105.

[41] Aronson, E., Wilson, T. D., \& Brewer, M. B. (1998). Experimentation in social psychology.

[42] Falk, A., \& Heckman, J. J. (2009). Lab experiments are a major source of knowledge in the social sciences. Science, 326 (5952), 535-538.

[43] Nielsen, R. (2012). Adoption of Jihadi Ideology by Islamic Clerics. Department of Government, Harvard University.

[44] Rogers, M, (1995). Diffusion of innovations. 4th edn, Free Press, New York.

[45] Moore, G. C., \& Benbasat, I. (1991). Development of an instrument to measure the perceptions of adopting an information technology innovation. Information systems research, 2 (3), 192-222. 